\title{
Means of Protection of Individual Rights in Public Administration - System and Efficiency ${ }^{1}$
}

\author{
Eva Sigmundová*
}

\footnotetext{
* Mgr. Eva Sigmundová, PhD student, Department of Administrative Studies and Administrative Law, Faculty of Law, Masaryk University. (e-mail: 392849@mail.muni.cz)
}

The monograph Means of Protection of Individual Rights in Public Administration - System and Efficiency is the result of a scientific project lasting for multiple years (2013-2016), managed by members of the Department of Administrative Studies and Administrative Law of the Faculty of Law, Masaryk University, Brno.

A much larger group of authors, comprising of almost thirty experts participated on this project. Apart from co-authors from the Czech Republic, also a large number of experts from the Slovak republic, Republic of Poland, representatives of Austria and Slovenia contributed to the realization of the book. Authors came from academic communities and application practice, including constitutional and administrative judiciary. Despite the large number of authors, the book is connected by linking articles which discuss the issue of the protection of individual rights in the area of administrative law and public administration.

It is a comprehensive work which will be certainly utilized by students of law as well as students from other fields of public administration studies. However, this is not a typical textbook, as the legal theory, as well as legal practice itself is very appropriately incorporated into individual chapters in which the authors express their own attitudes and views on the issue. It offers a clear and simple overview of all the basic institutes that in the Czech Republic could be used to protect individual rights within public administration, in an understandable way to nonprofessionals; the book is divided into three major parts.

The first part briefly, but in principle, deals with the role and activities of public administration, the issues of (subjective) rights, their protection but also the possibility of abusing these rights. The question whether the primary purpose of public administration is the protection of personal rights is being asked in this section. The authors answer the question negatively; nevertheless, they acknowledge that public administration provides protection of rights even so, all the more. The very content of the book is evidence that even in the field of public administration which is primarily not dedicated to protect rights, but to the administrate public affairs in the public interest, a relatively wide variety of resources can be found which could be considered as an instrument for the protection of rights. Based on this, the authors investigate answers for another question, i.e. whether the individual means of protection of rights form a coherent system and subsequently what is the actual effectiveness of these means of protection of rights. As a result, the book represents an imaginary mirror and feedback as it attempts to confront factual reality with legal status. 
The second part of the book represents its main part (pp. 41-366). The individual chapters focus on the general means of protecting individual rights that can be found in the exercise of administrative activity. The authors perceive the issue in the necessary European context, such as the actions of the Council of Europe and the European Union, including a model proposal for the European Union's Administrative Code. Following general institutes which can be considered as a means of the protection of individual rights in public administration, where the authors include the principles of good governance, the principles governing the performance of the administrative activity, or the work of the ombudsman, the following particular means for the protection of individual rights. In this regard the book is written mostly with respect to the factual figure and regulation of the Czech Republic. Among the specific means of protection of individual rights, which are subject to closer analysis, the authors present the procedural rights of the participants in administrative procedures, requirements for proper reasons for the decision, issues of ordinary and extraordinary remedies. Attention is paid to whether and how the protection of individual rights in other procedural processes is ensured, such as the conclusion of public contracts, the implementation of factual acts, the issuing of legislation by the public administration, the issuing of binding documents for the decision of the administrative authority, or the issue of measures of a general nature, which is a rather specific form of administrative activity, notably inspired by the German institute Allgemeineverfügung. In addition, the authors are also focusing on the selected areas of public administration where they are interested in whether and how individual rights are protected. For example, the area of self-government, immigration and asylum agendas, administrative penalties, or public services in state administration and security services.

The last part of the book is focused on the protection of individual (subjective) rights, in spite of the views of the authorities, Ombudsmen, administrative and constitutional judiciary, including the relatively provocative issues of the so-called ADR means that is also represented in this section.

Thus, the book goes from the general bases to individual institutes. Due to the systematic construction of the individual chapters it is not necessary to read the book chronologically, so the reader can focus only on the part that interests him/her. It is worth pointing out another advantage of this work, namely its practicality and connection with the reality of the legal world: an appropriate combination of theory, philosophy of law, practice, the opinion of experts from the field, as well as an outline of the issues and shortcomings brought by the currently established procedures. Therefore, we can look at issues from different angles which will give us a coherent picture of individual themes and allow readers to think and read their own attitude towards the subject.

The book is an interesting reflection of whether and how attention is paid in the Czech Republic to the protection of individual rights when the law provides a fairly wide range of instruments that can be used for this purpose. It focuses not only on the description of the legislation and legal status but attempts to take into account the actual functioning which is supplemented in some parts with specific statistical data and their evaluation. The essential contribution of this monograph lies in its practical functioning, in which it provides interesting and informative issues by presenting a variety of authors and opinions to the reader. 


\section{References}

1. Soňa Skulová \& Lukáš Potěšil (eds.), Means of Protection of Individual Rights in Public Administration System and Efficiency, 464 pages. (Praha, C. H. Beck, 2017). 